\title{
CrimRxiv
}

\section{Development as a}

Historical Component of

the UN Crime Policy

\section{Agenda: From Social}

Defence to the Millennium

\section{Development Goals}

Jarrett Blaustein ${ }^{1}$, Tom Chodor ${ }^{1}$, Nathan W. Pino ${ }^{2}$

${ }^{1}$ Monash University, ${ }^{2}$ Texas State University

Published on: Oct 23, 2020

DOI: $10.21428 / c b 6 a b 371 . e 7 c 971 a 9$

License: Creative Commons Attribution-NonCommercial-NoDerivatives 4.0 International License (CC-BY-NC-ND 4.0). 


\section{ABSTRACT}

This article presents a historical analysis of the intellectual and institutional origins of the international community's interest in the link between crime and development leading up to the adoption of the Millennium Development Goals in 2000. Drawing on a combination of documentary sources and interviews with long-time international crime policy insiders, it traces this interest back to the United Nations' (UN) social defence agenda which emerged in the aftermath of the Second World War. We situate this agenda in relation to the Western aspiration to advance the Modernization project and reflect on how its shortcomings together with ideological, economic, and geopolitical shifts at the international level contributed to the diversification of the UN's crime policy agenda during the 1970s. These conditions collectively influenced the international community's growing concern with crime as an existential threat to economic development during the 1980s. Our analysis highlights how this framing was reinforced by the rise of transnational organized crime as a threat to global capitalism following the collapse of the Soviet Union. It was against this historical backdrop that the United Nations Office for Drug Control and Crime Prevention (UN-ODCCP) was established to lead the international community's fight against 'uncivil society'. We conclude by reflecting on UN-ODCCP's tumultuous early years along with the omission of 'crime' from the Millennium Development Goals and suggest that these conditions, along with the adoption of the United Nations Conventions Against Transnational Organized Crime and Corruption, set the stage for the organisation's future advocacy for the inclusion of crime in the Sustainable Development Goals.

\section{INTRODUCTION}

Crime prevention has only recently gained formal recognition as a global sustainable development priority (see Blaustein, Pino, Fitz-Gibbon and White 2018) but development has long featured as an important thematic component of the United Nations' (UN) crime policy agenda. This article sets out to document how the UN's framing of the relationship between crime and development evolved from the aftermath of the Second World War to the adoption of the Millenium Development Goals (MDG) and accounts for various factors that contributed to key shifts. $\underline{1}$ Our historical analysis is based on our reading of more than two-hundred publicly available primary source documents that provide an official record of UN crime policy activities and priorities since 1947/8. We further supplemented our reading of these documents with data from oral-history interviews conducted with seventeen veteran UN crime 
policy insiders who occupied senior leadership or advisory roles between the early 1970 s and 2018.

Noting that development was not a major thematic component of the international crime policy agenda under the League of Nations (Knepper, 2011), we begin by reflecting on the theoretical assumptions that underpinned the establishment of the UN's Social Defence Section of the Secretariat in the late 1940s. Specifically, we account for how a prevailing belief in the Modernization thesis together with the criminological theories of the Chicago School influenced the work of the Social Defence Section and their efforts to develop an international knowledge base to combat the anticipated criminological consequences of rapid industrialisation and urbanization throughout the recently decolonised Global South. Noting the financial difficulties of the Social Defence Section, we then proceed to consider how and why the discursive framing of the relationship between crime and development evolved throughout the 1970s and 1980s in response to: declining institutional support for the Social Defence Section; political developments associated with the rise of the New International Economic Order (NIEO); advances in criminological theory; and the gradual and uneven spread of neoliberal ideology. We argue that these factors collectively contributed to the diversification and internationalisation of the UN's crime policy agenda and an important shift in how the UN framed the relationship between crime and development from the 1980s onwards. Henceforth, crime was treated predominantly as a threat to economic and later social development.

With the remainder of the article, we reflect on how the emergence of transnational organized crime as the overarching focus of the UN's crime policy agenda since the 1990s helped to solidify this understanding of crime as a threat to development. We argue that this growing interest in transnational organised crime can be attributed to heightened concerns among Western powers and international organizations about the 'dark side' of neoliberal globalization. It was against this historical backdrop that the United Nations Office for Drug Control and Crime Prevention (UN-ODCCP) was established in 1997, and the United Nations Convention against Transnational Organized Crime (A/RES/55/25; henceforth UNTOC) adopted three years later. We conclude by accounting for the tumultuous early years of UN-ODCCP which were compounded by the omission of any mention of crime, justice or security in the MDGs. As detailed elsewhere (Blaustein, Chodor and Pino, in-press), it was against this historical backdrop that UN-ODCCP, which later became the United Nations Office on Drugs and Crime (UNODC), initiated a programme of advocacy that directly 
contributed to the institutionalization of the idea that crime constitutes a threat to development as part of the 2030 Agenda for Sustainable Development. $\underline{2}$

\section{A NOTE ABOUT HISTORIOGRAPHY AND METHODS}

The primary aim of this article is to 'contribute to historical knowledge' about the crime-development nexus for the purpose of advancing 'a deeper understanding of problems in the present by questioning the historical origins of practices and institutions' (Knepper and Johansen, 2016: 5). Within the field of criminology, our historiographic approach is somewhat distinct from the four traditions identified by Lawrence (2016) although elements of our analysis of UNODC's efforts to promote the crime-development nexus which are the focus of the sister article (Blaustein, Chodor and Pino in-press) certainly resonate with cultural approaches that examine 'the notion of crime as a constructed social and cultural discourse' (Lawrence, 2016: 29). $\underline{3}$ The analysis presented in this article however was influenced most directly by previous historical studies of other UN organisations (for example, Murphy, 2006), criminological studies of crime policy development in England and Wales, Ireland and Scotland (see Loader, 2006; Rock, 2002; Brangan, 2019a; Brangan, 2019b), and critical policy sociologists who study 'the conditions that make the emergence of a particular policy agenda possible' (Gale, 2001: 387).

Our historical analysis is primarily informed by our reading of an abundance of documentary sources that were publicly available via UN websites and online databases. These sources included: official transcripts and summaries of UN meetings, debates and assemblies; UN Yearbooks; official documentation relating to quinquennial UN Conferences on the Prevention and Criminal Justice; UNDP Human Development Reports; reports by the World Bank and other international financial institutions; documentation relating to the creation of UNODC; and documentation relating to the adoption of UNTOC and the United Nations Convention Against Corruption (A/58/422; UNCAC). We compiled this material into a digital archive and analysed it over an extended period of time to develop an overarching sense of how development has historically featured as an element of the UN's crime policy agenda. In the first instance, we read these documents chronologically before undertaking a more detailed analysis of key documents and sections for the purpose of identifying key events and factors that help to explain key shifts in the framing of the relationship between crime and development. We then set out to triangulate and contextualize our analysis by drawing from 'insider' accounts of UN crime policy (e.g. Lopez Rey, 1957; 
Lopez-Rey, 1985; Clifford, 1979; Clark, 1994; Redo, 2012; Joutsen, 2017), along with various scholarly literatures.

Additional detail was supplied via oral history interviews with seventeen international crime policy insiders who were actively involved with the UN crime programme during various periods between the 1970s and 2018. 4 Our decision to interview these individuals was informed by the institutionalist approaches to theorizing global governance whereby bureaucratic actors, in this case the UN Secretariat, are said to play an important role when it comes to facilitating the development and implementation of international policy agendas (Barnett and Finemmore, 1999). This perspective remains under-explored within the wider historical and theoretical literature on international crime policy formation, and is especially apt for understanding historical efforts to frame and reframe international discourse relating to the crime-development nexus because a) crime has never been a major international policy priority for powerful countries and b) the UN has always been at the centre of its governance. Thus, while it must be acknowledged that UN entities cannot make policy and are not permitted to influence policy or lobby member states, they do engage in advocacy work, facilitate key events such as the quinquennial UN Congresses on Crime Prevention and Criminal Justice, and produce research and discussion papers that may help to increase the visibility of specific issues or agenda items. The participants we interviewed for this article engaged in all of these activities, many of which are not accounted for in official UN documentation. They also observed first-hand the efforts of different Member States to shape the international crime policy agenda. As such, participants' testimonies add an important perspective to our understanding of how and why the UN's crime policy agenda has evolved since the 1970s.

Ten of the interviews were conducted via Skype, six in-person, and one via email correspondence. The interviews lasted between 45 minutes and two hours. All but four were audio recorded with participants' consent. Some quotes have been edited to protect the identity of participants, albeit in such a way as to preserve the substance and emphasis of the original quote. For example, accents and biographical details have been removed or altered, and in some cases, the first-person has been changed to third-person to obscure the nature of the participant's involvement with the events being described. De-identifying the data in this manner was essential due to the politically sensitive nature of the issues that were discussed and the openness with which participants discussed them. 


\section{CRIME, MODERNIZATION AND SOCIAL DEFENCE}

International efforts to govern and respond to crime as a transnational issue predate the establishment of the UN system. For example, Knepper (2009: 2) describes how the League of Nations (1919-1938) 'had several technical organisations which had to do with aspects of crime'. Development, however, was not a significant concern of these early initiatives, nor was it a priority for the Social Defence Section which formed part of the Social Development Division of the UN Secretariat until the early 1950s (Redo, 2012; Joutsen, 2017). $\underline{5}$ The first documented reference to a possible link between social development and crime was during a meeting of the UN's Economic and Social Council (ECOSOC) in 1953 which resulted in the commission of an empirical study on 'the prevention of types of criminality resulting from social changes and accompanying economic development in less developed countries' (see United Nations, 1960: 1). The study, published seven years later, supplied vivid characterizations of the criminogenic consequences of rapid industrialization and urbanization in what were then referred to as 'less developed' countries (Panakal and Khalifa, 1960). The prevailing theory of socioeconomic development underpinning this study was the Modernization thesis which postulated that economic and social development in recently decolonized nations would follow the trajectories of their former colonizers in the industrialized West (Rostow, 1960). The concern was that in the industrialised West, this trajectory of capitalist development was widely understood to generate social instabilities as government policies stimulating industrialization led to rapid urbanization, as people migrated from rural to urban areas in search of work. Prominent American criminologists of the era argued that these transformations resulted in social instabilities and anomie that were in-turn conducive to rising levels of urban criminality. $\underline{6}$ The ECOSOC report echoed these ideas and the Modernization thesis subsequently emerged as the dominant sociological paradigm underpinning the UN's Social Defence Section during the 1950s and 1960s (Ancel, 1965).

As with the broader use of Modernisation Theory by the leading Western states and global institutions during this period, the concern with the instability caused by capitalist development reflected a fear of the potential for a 'communist takeover' if such instability got out of hand. It was no coincidence that Rostow (1960) subtitled his book "A Non-Communist Manifesto" reflecting a desire by Western actors to manage the transition of the 'Third World' to capitalism on their ideological terms, ensuring its transaction costs would not undermine the whole project. A consequence of this was that the production of UN knowledge about crime was inherently skewed 'to the 
northern Anglophone world' and Northern expertise was privileged over that from the South (Carrington and Hogg, 2017: 181; Walters, 2001).

Unsurprisingly, Western criminologists from the United States and its allies had a significant influence upon how criminological issues were framed and addressed by ECOSOC through their participation in expert advisory committees (see Clark, 1994: 19-23). To this effect, the 1954 UN Yearbook described how '[t]he social defence programme was increasingly directed towards assisting the underdeveloped countries through making available to them the experience of countries more advanced in the prevention of crime and the treatment of offenders' (United Nations,1954: 262). The paternalistic overtones of this statement are readily apparent but it is important to emphasize that Member States themselves often disagreed about how causes of crime should be framed and how these should be addressed through social defence initiatives or criminal justice reforms. An example of this is evident from the proceedings of a debate between Member States about the causes of juvenile delinquency held during the First UN Congress on the Prevention of Crime and the Treatment of Offenders in 1955 (see United Nations, 1955: 60). Yugoslavia's representative openly rejected the idea that 'materialism' was contributing to social disorganization in his country or increasing juvenile delinquency. The representative from the Philippines then called upon delegates to acknowledge the importance of religious bodies in preventing juvenile delinquency. This request was rejected however by the Juvenile Delinquency Rapporteur, prominent American criminologist Paul Tappan, who stated 'that he was unable to support the amendment as it might be taken to mean that some countries gave religion insufficient attention or that, in countries which placed less emphasis on religion, religious bodies were not called upon to play an important part in the prevention of juvenile delinquency' (United Nations, 1955: 60).

The impact of such debates on the content of the UN crime policy agenda is difficult to gauge from documentary sources alone but the example evidences that the theoretical influence of sociological positivism amongst UN crime policy experts during the 1950s and 1960s did not produce a consensus amongst Member States themselves. For this reason, documents produced by the UN Secretariat have historically featured caveats about the need to avoid universalistic assumptions and generalizations about the causes of crime. The inclusion of such caveats represented an important ideological compromise: it privileged expert knowledge while maintaining a space for Member States from across the ideological spectrum, including the Soviet Union, to take part in key discussions and debates (Lopez-Rey, 1985: 1). In the context of a bipolar international system, ensuring their participation was crucial for legitimizing the UN's 
work on social development issues. This was particularly important in the early decades of the Cold War when the UN's primary financial benefactors were the United States and its Western allies.

\section{THE DIVERSIFICATION OF THE UN'S CRIME POLICY AGENDA}

Social defence was never high on the UN's policy agenda but by the late 1960s, the financial viability of the Social Defence Section was cast in doubt. To this effect, William Clifford who was the Director of the UN's Social Defence Section during the 1970s later reflected that 'problems of crime and rehabilitation' came to be seen within ECOSOC as 'anachronistic and better treated within the larger context of total social improvement' (Clifford, 1979: 17). Clifford went on to describe how by 1970 the Social Defence Section's budget had declined to such an extent that 'in a greatly enlarged \$500 million [UN] programme covering all fields of development..., the subjects of crime prevention (or social defence), could ... barely raise a single UN expert in the Third World and perhaps an occasional six months fellowship' (Clifford, 1979: 17)..$\underline{7}$

Concerns about the sustainability of the UN's crime policy apparatus prompted members of the Section to adopt the position that the nature of crime was changing and that this necessitated greater international cooperation in order to understand and address this emerging threat. To this effect, a 1970 working paper published by the Secretariat asserted:

Planning is no longer a purely national concern. The countries of the world are becoming progressively more interrelated and the responsibility for achieving better standards of living for all is a burden shared by developed and developing nations alike. (United Nations, 1970: 40)요

In 1971, the Social Defence Section was rebranded the Crime Prevention and Criminal Justice Section (CPCJS) and the following year, a special Working Group of the Committee on Crime Prevention and Control (CCPC) was tasked with developing an 'International Plan of Action' for crime prevention (Redo, 2012: 152). As noted by Clifford, one of the Working Group's three foundational principles similarly emphasized the importance of the UN's work on crime by describing crime as 'a distinctly international problem' (quoted in Clifford, 1979: 31). This also reflected the first signs of globalisation, as transnational corporations were beginning to integrate the developing world into the global economy, thus connecting it to criminal problems that spanned across borders. 
In 1974, the CPCJS was 'upgraded' to the Crime Prevention and Criminal Justice Branch (CPCJB; see Redo, 2012: 151) and the increasingly 'transnational' character of criminal activity was subsequently described by the Secretariat in a 1975 working paper titled 'Changes in Forms and Dimensions of Criminality- Transnational and National' (United Nations, 1975a). This working paper provided an overview of trends relating to a diverse array of criminal activities and offence categories (e.g. organized crime, cultural trafficking, corruption, and criminality associated with migration) that had previously fallen beyond the scope of the UN's crime policy remit (see United Nations, 1975a). These issues, together with the idea that crime had become a transnational phenomenon, subsequently became the crux of the UN's crime policy agenda throughout the 1980s.

The CCPC's efforts to promote recognition of crime as an increasingly complex, transnational problem represented a clear departure from the UN's earlier focus on social defence but the emergence of this narrative was not so much an innovation as a reversion to historical narratives about the international crime problem that had once underpinned the work of the League of Nations (see Knepper, 2011). To this effect, the 1970 Secretariat report explicitly acknowledged that the problem of controlling and preventing crime has been recognizedly (sic) international since nations first began to associate for their mutual advantage' (United Nations, 1970: 40).

It is also important to acknowledge that the diversification of the UN crime policy agenda coincided with a broader ideological shift which played an important role in redefining North-South relations within the UN system during the final decades of the Cold War. Simply, the arguments of dependency theorists (e.g. Cardoso, 1972; Dos Santos, 1970) stimulated a critical dialogue amongst 'Third World' states about the international community's paternalistic approach to economic and social development (Rist, 2014). This discourse gave rise to the New International Economic Order (NIEO) ideology which subsequently 'became an essential element in practically every [UN] discussion and was brought into criminal policy' (Lopez-Rey, 1985: 93). A consequence of this ideological realignment was that the work of the Secretariat became less insulated from the politics of the UN system (see Murphy 1984). Western expertise continued to dominate the work of the CCPC until it was ultimately replaced by the Commission on Crime Prevention and Criminal Justice (CCPC) in 1992, yet the paradigm of social defence with its neocolonial connotations (see Walters, 2001) became inherently difficult to sustain due to the Third World's efforts to assert its cultural, economic and political autonomy. For some UN crime policy insiders, this was in fact a welcome development because it created an opportunity to establish crime 
prevention 'as a free-standing item' within ECOSOC's portfolio, thereby distancing it from the UN's agendas on economic and social development (Clark, 1994: 4). To this effect, one of the original architects and long-time contributors to the UN crime programme, Manuel Lopez-Rey, reflected that '[crime prevention] had been frequently overlooked because of the importance attached to the badly defined concept of development' (Lopez Rey, 1985: 125).

Amidst these changes, the international community's interest in the relationship between crime and development did not simply disappear. Rather, its understanding of the nature of this relationship evolved. Henceforth, emphasis was placed on the importance of understanding and addressing 'the serious threat that criminality presents to the quality of economic and social development and to the wholesomeness of economic and social progress and change' (Criminality and social change, E/RES/1584(L)). Echoing this sentiment, the CPCJB published a working paper in 1975 examining the 'Economic and Social Consequence of Crime' (United Nations, 1975b). The opening paragraph of the report stated:

That crime exacts a price in human and material terms is generally admitted. How sizeable is this price? What are its elements, ramifications and repercussions on society as a whole and on the groups within it? The answers are still large and unknown. In order to deal with crime more effectively and to devise more successful prevention strategies, much more has to be known about the impact of crime on different segments of the population, on the economy, on national development and on the quality of life. (United Nations, 1975b: 3)

The Secretariat later elaborated on the multi-form nature of the economic and social costs of crime in a series of reports that were published throughout the 1980s. For example, a 1980 Secretariat working paper suggested:

[a] state of uncertainty about life and property, induced by high rates of criminality or a lack of suitable efforts to control it, will result in considerable direct and indirect costs to the national economy and the society as a whole. It will also encourage an unwillingness to take risks, a rise in interest rates and insurance premiums, and an inflation spiral that will seriously impair the quality of life for citizens (United Nations, 1980: 6).

Five years later, the Secretariat elaborated on these economic costs by suggesting that 'growing crime rates often force Governments to divert increasing shares of their 
overall income to their crime prevention and criminal justice systems.' (United Nations, 1985a: 11).

The UN never wholly abandoned the idea that structural changes associated with economic and social development are criminogenic (e.g. United Nations, 1990). Rather, it adopted a more nuanced stance regarding the potential for international cooperation to 'foster balanced development, through restructuring of the international economic system, with due emphasis on crime prevention and the proper functioning of criminal justice systems' (United Nations, 1985b: 8). This position reflected NIEO's lingering influence over ECOSOC and the General Assembly in the wake of the Caracas Declaration (see United Nations, 1985b). This is evident from the language of the Milan Plan of Action adopted at the Seventh UN Crime Congress in 1985. $\underline{9}$ Here it was agreed that '[d] evelopment is not criminogenic per se' but rather, 'unbalanced or inadequately planned development contributes to an increase in criminality' (United Nations, 1985c: 3, original emphasis). The implication was that the root of the problem was not development itself, but rather the inequality resulting from inappropriate or poorly implemented development models. Although clearly influenced by NIEO ideology, this shift of rhetoric was also consistent with advances in criminological theory during the late 1970s when inequality emerged as a major focus (e.g. Blau, 1977; Krohn, 1976; Messner, 1982). To this effect, the 1985 report of the Secretariat echoed the basic hypothesis underpinning many of these studies in arguing that 'increasing poverty and economic deprivation will push growing numbers of people, ordinarily respectful of law and order, into trying to satisfy their basic needs through criminal or deviant behavior' (United Nations, 1985a: 27). This also reflected the growing realisation of the 'lost decade' for much of the Global South, as the impacts of the 1982 Debt Crisis and subsequent structural adjustment plunged many developing countries into deep economic crises which frayed their social orders and led to growing poverty, instability and insecurity.

Finally, it is important to consider that the shifts described in this section coincided with the gradual and uneven spread of neoliberal ideas and development policies (Harvey, 2005; McMichael, 2017). The UN was never fully inculcated into neoliberalism as a global political project and one of our informants suggested that neither the CCPC or CPCJ actively used its influence to promote neoclassical crime control policies that have since come to be associated with the development of the penal state (e.g. Wacquant, 2009). Nevertheless, elements of the Secretariat's framing of the relationship between crime and development throughout the 1970s and the 1980s appeared to become increasingly compatible with some core neoliberal doxa. 
For example, the previously quoted excerpt from the 1980 Secretariat report suggests that the well-being of individuals is inherently linked to the health of the national economy and that the absence of social stability and order constitutes a risk for prospective international lenders and investors (United Nations, 1980). As discussed in the following section, the rise of transnational organized crime and corruption from the mid-1980s further signified acceptance by members of the CPCJB that it must define a sustainable role for itself in relation to this emergent economic development paradigm and geopolitical shifts. This was particularly important because in 1980, the CPCJB as part of the Centre for Social Development and Humanitarian Affairs (CSDHA) was relocated to Vienna from New York meaning that the UN crime programme was subsequently forced to operate on the fringes of the wider UN system (Redo, 2012: 152).

Adaptation certainly provides one compelling explanation for this discursive shift yet a simpler explanation was also provided by one of our informants who had been directly involved with the CPCJB at the time. In their opinion, any textual references to crime as a development issue in Secretariat reports published in 1980 or 1985 were likely attributable to one long-serving member of the CPCJ who was 'very passionate on this' (Interview, Participant 10). According to this informant, Irene Melup who had worked for the Secretariat on crime-related issues since the late 1940s 'did her damnest to push [her criminal justice ideology] forward through the Branch and the Committee'. Highlighting this explanation is important because it demonstrates that throughout the Cold War, important continuities existed within the UN's crime policy apparatus despite the ideological, institutional and material shifts discussed. Often this agency took the form of individuals who devoted their professional lives to advancing the work of the Secretariat behind the scenes.

\section{THE GLOBALIZATION OF CRIME}

During the 1990s, transnational organized crime emerged as the dominant focus of the UN's crime policy agenda. This coincided with the decision to relocate the CSDHA back to New York yet keep the CPCJB in Vienna in 1992. As Redo (2012: 152) argues, this rendered the CPCJB 'a Branch with no tree' and effectively severed the entity's link to the work of the UN development system. That same year, the member state-led CCPCJ replaced the CCPC as the CPCJB's governing body in 1992. As one participant explained:

The shift from an expert-driven UN Crime Committee to a government-driven UN Crime Commission resulted in a growing emphasis on organized crime and 
transnational criminal justice (international law enforcement and judicial cooperation, measures which, significantly, are the responsibility of the state), with a corresponding decrease in the attention devoted to so-called ordinary crime and the day-to-day working of the criminal justice system. (Interview, Participant 14; see also Clark, 1994)

The issues of transnational and organized crime had previously gained some recognition amongst UN crime policy insiders and Member States during the 1980s (United Nations, 1985a) but another participant reflected that the end of the Cold War sparked heightened global awareness of the 'perceived risk of [the] internationalization of organized crime':

Once organized crime got involved into money laundering and financial transactions, so it went beyond the borders of one country and became crossborder, it became alarming and it was realized that it was not only the Italian mafia or whatever mafias were there in the US...but the Russian mafia appeared... [then] the Chinese triads.... [then] the revival of African mafias...the Albanian mafia...So indeed mafias became an international phenomenon. (Interview, Participant 13)

The end of the Cold War also gave rise to what this same participant described as 'the golden age of international cooperation'. 'Crime problems' thus became increasingly 'universalized' within UN policy discourse and this prompted greater interest in 'generalized control responses' (paraphrasing Findlay, 1999: 224). Thus, in 1994 the UN organized an influential conference on financial aspects of organized crime in Naples in 1994 where the head of the United Nations Office in Vienna Giorgio Giacomelli observed that "The transition from a controlled to a free-market economy in [former post-Soviet countries] opens up so many possibilities for criminal transactions' (Giacomelli quoted in Cowell, 1994: A17 as cited by Shelley, 1995).

Perceptive of both the threats and opportunities posed by neoliberal globalization as the emergent economic paradigm (McMichael, 2017), members of the UN Secretariat and the CCPCJ adopted an ambivalent understanding of the relationship between crime and development. Simply, economic globalization was seen to create new opportunities for transnational organized crime to flourish and it was believed that the impact of this trend was likely to be greatest in the Global South. To this effect, a 1995 working paper prepared by the UN Secretariat asserted '[t]aking advantage of the dominant economic trends of the 1990s - globalization and liberalization transnational crime is now a major force in world finance, able to alter the destinies of 
countries at critical stages of their economic and social development' (United Nations, 1995: 1). At the same time, the working paper goes on to describe 'the tendency of transnational crime to subvert the benefits of globalization and liberalization, on which industrialized as well as developing countries are pinning their hopes on economic growth' (United Nations, 1995: 1). This suggests that economic globalization was seen as both the driver and the casualty of transnational organized crime. As the purported benefits of neoliberal globalisation failed to materialise in many developing countries, its proponents begun focusing on the potential obstacles to their realisation in order to counter a brewing backlash against the whole project.

In 1995, delegates at the Ninth Congress on the Prevention of Crime and Treatment of Offenders pushed transnational organized crime to the top of the UN's crime policy agenda by 'urging Member States to consider the establishment and reinforcement of cooperation, inter alia, practicable arrangements for the effective prevention and control of transnational and organized crime' (United Nations, 1995: 5). Over the five years that followed, members of the UN's crime programme actively worked with Member States to develop an international legal order to address this problem. $\underline{10}$ These efforts culminated in the adoption of UNTOC in 2000 in addition to the establishment of UN-ODCCP in 1997. The remainder of this article reflects on the tumultuous formative years of UN-ODCCP and the omission of crime from the MDGs.

\section{'A MISSED OPPORTUNITY'}

UN-ODCCP was established in 1997 through a merger between the CPCJD and the Vienna-based UN's Drug Control Program (UNDCP). As Redo (2012: 153, original emphasis) argues, the merger prompted Secretary-General Kofi Annan 'to designate Vienna as the centre of the United Nations fight against uncivil society, i.e. those elements which take advantage of the benefits of globalization by trafficking human beings and illegal drugs, laundering money and engaging in terrorism.' UN-ODCCP's prescribed mandate represented an important obstacle for the organization because it was seen by other UN actors to contrast with the wider progressive aims and outlook of the institution. The Vienna location of UN-ODCCP was problematic for two reasons. First, the agency's location in Vienna instead of New York signified that its portfolio was of marginal importance to the overarching aims of the UN system. Under Kofi Annan, the priority was development. Second, in practical terms, the geographic distance between New York and Vienna has historically limited UN-ODCCP and later UNODC's ability to shape the wider UN agenda (Interview, Participant 12). 
It is also worth noting that prior to 2002/3, there was little overlap between the work of UNDCP and the crime division which was once again re-branded as the Centre for International Crime Prevention (CIPC) circa 1997. As one participant explained:

So, you had two entities - UNDCP on the drug side and CIPC, and with a completely different culture in terms of the work of these two entities, in terms of the composition of the staffing, and so on...But they were served by one Executive Director, one cabinet, and there were some elements of their programmes that were pulled together - like for instance, on the issue of money laundering...but still the entities were separate and the culture, as I said, was very, very different until 2002/2003. (Interview, Participant 7)

In the late 1990s, UNDCP was 'ten times bigger than the crime [programme]' and accounted for nearly almost all of the newly established UN-ODCCP's funding (Interview, Participant 11). This disparity can be explained by the fact that UNDCP already had an operational mandate with the 1988 United Nations Convention Against Illicit Trafficking in Narcotic Drugs and Psychotropic Substances (E/CONF.82/15) and a wealthy sovereign backer that supported the UN General Assembly's call for a 'drug free world' by 2008: the United States (see Political Declaration, A/RES/S-20/2). By contrast, the CIPC lacked an operational capacity and a normative mandate to develop one until 2001. Unsurprisingly then, between 1997-2002 drugs served was the main strategic priority for UN-ODCCP's Executive Director Pino Arlacchi (1997-2002).

Arlacchi was a UN outsider whose only evident qualifications for the job were his background as an academic sociologist who had written about the mafia (see Arlacchi, 1986) and the reputation he gained as a crime fighter in Italy where he had served as the vice-president of Italy's Anti-Mafia Commission in the 1980s and subsequently, as an elected member of the Italian Parliament (Interview, Participant 1). Accordingly, one participant suggested that Arlacchi 'had great ambitions and plans...to make the crime components of UNODC much bigger and much more powerful' (Interview, Participant 11). His desire was for UNODC to 'play a major role in addressing emerging international crime problems' by developing the CIPC's operational capacities (Interview, Participant 11). Arlacchi's aspirations thus reflected his own expertise along with Italy's role in pushing the issue of transnational organized crime to the top of the international crime policy agenda.

UN-ODCCP's greatest success during the Arlacchi years was its facilitation of the negotiation of UNTOC and the Protocols in only two years. Adopted in 2000, UNTOC established a normative framework that subsequently allowed UN-ODCCP and UN- 
UNODC to finance projects and programmes that focused on crime. Staff at UNODCCP were instrumental when it came to driving these negotiations behind-thescenes $\underline{11}$ but Arlacchi's aspiration for the CIPC to become a global leader in the fight against transnational organized crime represented a departure from its previous work (Clark, 1994). This sparked a conflict between Arlacchi and long-serving staff who 'were more interested in negotiating and adapting more and more norms and standards for crime prevention and criminal justice' (Interview, Participant 11; see also Transnational Institute, 2005).

Arlacchi reportedly dealt with this dissent by relocating his detractors from the Head Office in Vienna to various field offices around the world. One participant who claimed to have been subjected to this reflected: 'It was sort of a political exile because I was actually kicked out, transferred against my will...I was not the only one that it happened to that time' (Interview, Participant 13). Allegations of this practice were also documented in a confidential resignation letter penned by one of UN-ODCCP's Directors, Michael vd. Schulenberg, in December 2000.1ㅡ More significantly, Schulenberg's letter contained allegations of misconduct by Arlacchi and criticism of his management style. In an excerpt from the letter, vd. Schulenberg stated that UNODCCP under Arlacchi is 'an organization that has increased its international visibility while at the same time, is crumbling under the weight of promises that it is unable to meet under a management style that has demoralized, intimidated and paralyzed its staff' (Michael vd. Schulenberg, quoted in Transnational Institute, 2005).

The letter was leaked to the press (see 'U.N. drug control office in disarray', 2001) and the following year, UN-ODCCP was subjected to both an inspection and a formal investigation by the UN's Office of Internal Oversight Services (OIOS). The inspection, conducted in February 2001, provided a damning assessment of UN-ODCCP under Arlacchi's leadership (Office of Internal Oversight Services, 2001a: 14). The subsequent investigation cleared Arlacchi of any misconduct but concluded that 'multiple incidents of mismanagement of project operations and waste of ODCCP funds occurred' (see Office of Internal Oversight Services, 2001b: 2). The investigation and the media attention it attracted tarnished UN-ODCCP's credibility with donors. This jeopardized the organization's financial viability at a time when major donors were already shifting their diminishing aid budgets towards specific programmes or projects that aligned with their interests (referred to as 'voluntary contributions'), rather than the core UN budget which makes up the General Purpose Fund (Browne, 2011). For UN-ODCCP, this was particularly concerning because the adoption of UNTOC and 
UNCAC created a need for the organisation to access funding in order to expand and develop its operational capabilities.

As documented elsewhere, the UN's changing funding landscape after the Cold War had a significant impact on the actual work and bureaucratic politics of the UN system (Murphy, 2006; Blaustein, 2015). On the one hand, it coincided with a significant increase $(\approx 180 \%)$ in the overall UN budget between the years 1995 and 2010 (Naik, 2013) with $\approx 71 \%$ of this funding coming from non-core contributions in 2010 , compared to only $\approx 36 \%$ in 1995 (Naik, 2013). This illustrates that donors have been willing to contribute more to the work of the UN through non-core contributions as it affords them greater control over how their money is spent (Murphy, 2006). For UN entities, this shift has led to decreased autonomy because they must design and implement programmes and projects that align with the immediate interests of donors. This, in-turn, has prompted UN entities to embrace 'results-based management' (RBM) as a framework for strengthening accountability to donors (Blaustein, 2015). More problematically, the scarcity of core funding and the attractiveness of donor funding has fuelled a competitive dynamic within the UN system. In other words, different UN entities must continuously convince donors and other stakeholders of the significance and timeliness of their portfolios. This dynamic has at times undermined inter-agency coordination and cooperation, as different UN entities increasingly find themselves competing for the same donor funding. Accordingly, strategic communications and advocacy have emerged as important components of their efforts to sustain operations.

Prior to the investigation, UN-ODCCP was certainly not immune to these pressures, nor was Arlacchi ignorant of the need for the organisation to convey the importance of its work to donors. Rather, Arlacchi was described by participants as having a narrow vision for the UN's crime programme that reflected his aforementioned interest in organized crime. Over time, this issue did prove to be financially lucrative for the organization, but in the lead-up to the MDGs, this myopia meant that UN-ODCCP seemingly missed out on the opportunity to construct a compelling narrative about the importance of its work in relation to the wider UN agenda. As one participant reflected:

The negotiations for the Millenium Development Goals had already started by 1998. By 1999, crime and drugs didn't feature highly on the agenda. The agenda was still very much about poverty reduction and crime was not given a place on it. [UN-ODCCP] made a last chance effort to get the Viennese agenda a place in the Millennium Goals but it was too late... Arlacchi himself didn't see so much the links between crime control and sustainable development...He was not a person 
with any prior interest in development aid. That was not his background. (Interview, Participant 11)

This 'last chance effort' is evident from the content of a statement delivered by Arlacchi to the Third Committee of the UN General Assembly in September 2000, just three-weeks after the Millenium Declaration was signed:

We are encouraged that the Summit included in the Declaration a series of commitments to strengthen respect for the rule of law and to act against the drug problem, terrorism, the arms trade, economic crime and transnational crime in general...I am absolutely certain that we can defeat the uncivil society. The linkages between poverty and the areas of responsibility given to ODCCP are perhaps one of the least understood aspects of our work. Yet it is one of the most important...We are working in some of the poorest areas of the world. This is not by chance. We are also working in some of the most violent locations. Again this is not by chance. Poverty alleviation without the rule of law is not an option. It will simply not work. (Arlacchi, 2000)

Unfortunately, leading architects of the MDGs in New York 'thought the idea that you can promote sustainable development through fighting crime was bullshit' (Interview, Participant 11). $\underline{13}$ The prospect of convincing them of the importance of this link was further undermined by the fact that at this time, 'the evidence that crime control or drug control could make a contribution to sustainable development was not so strong, it was more a hypothesis' (Interview, Participant 11).

The omission of 'crime' and 'rule of law' from the MDGs was therefore seen as a 'missed opportunity' by many at UN-ODCCP (Interview, Participant 4), but it created an impetus for the organization to reassess how its portfolio fit with the aims of the wider UN system. Almost immediately, the CIPC attempted to develop an evidence base that could be used to highlight the links between crime and development. For example, in 2001 the Officer-in-Charge of the CIPC, Professor Jan van Dijk, published an article titled 'Does crime pay? Exploring the relationships between crime, rule of law and economic growth' in the inaugural issue of UN-ODCCP's in-house journal, Forum on Crime and Society (see van Dijk, 2001). The impact of the article is unclear but it provides an early illustration of how the organization would subsequently use its research to establish an evidence base to support its strategic advocacy work to ensure crime was included in the Sustainable Development Goals (Blaustein, Chodor and Pino, in-press). 


\section{CONCLUSION}

This article has detailed how economic and social development have long featured as important thematic components of the UN's crime policy agenda. It has also highlighted the fact that crime has long been recognised as a global issue throughout the UN system. This suggests that the intellectual and institutional origins of the crimedevelopment nexus as a fixture of the 2030 Agenda can be traced back to (at least) the 1950s. Whereas the 'social defence' approach initially framed crime as a potential consequence of capitalist development, the diversification of the UN's crime policy agenda together with the onset of neoliberal globalization reversed the emphasis, and crime was thereafter presented primarily as an obstacle or a threat to economic development. Transnational organized crime soon emerged as the dominant focus of global crime policy and this directly contributed to the establishment of UN-ODCCP and the adoption of UNTOC. As Joutsen (2017: 3) has argued, the adoption of UNTOC and later UNCAC were particularly significant insofar as they brought about an important transition in the history of the UN's crime programme. Whereas previously, it had relied on ineffective 'soft-law resolutions' that focused on crime as a domestic issue, the Conventions established a clear, Member State-sanctioned mandate for the UN to address crime and corruption as global problems. Despite this paradigmatic shift, continuity can also be seen in the international community's overarching aim when it comes to governing the nexus between crime and development. For more than seventy-years, that aim has been consistent with the design of liberal global governance as a larger political project: to create and maintain orderly societies within which some form of capitalism, be it Keynesian, neoliberal or post-neoliberal, can flourish (Murphy, 1994). As detailed in Blaustein, Pino, Fitz-Gibbon and White (2018), this aspiration sits at the heart of SDG 16 today which seeks to 'promote peaceful and inclusive societies for sustainable development'.

\section{REFERENCES}

Amuso, V. (2015) 'Global Policy Interview with Pino Arlacchi: Transnational Organized Crime.' Global Policy. February 9. Retrieved from:

https://globalpolicyjournal.com/blog/09/02/2015/global-policy-interview-pino-arlacchitransnational-organized-crime (Accessed 11 October 2018)

Ancel, M. (1965) Social Defence: A Modern Approach to criminal Problems. London: Routledge. 
Andreas, P. and Nadelmann, E. (2006) Policing the Globe. Oxford: Oxford University Press.

Arlacchi, P. (1986) Mafia Business: The Mafia Ethic and the Spirit of Capitalism. London: Verso.

Arlacchi, P. (2000) Statement of Pino Arlacchi to the Third Committee of the General Assembly. 29 September. New York. Retrieved from: <https://www.unodc.org/unodc/en/about-unodc/speeches/speech_2000-09-29_1.html> [Accessed 17 November 2018]

Barnett, M. and Finnemore, M. (1999) 'The Politics, Power, and Pathologies of International Organizations', International Organization, 53(4): 699-732.

Blau, P. (1977) Inequality and Heterogeneity. New York: Free Press.

Blaustein, J. (2015) Speaking Truths to Power: Policy Ethnography and Police Reform in Bosnia and Herzegovina. Oxford: OUP.

Blaustein, J., Pino, N. and Ellison, G. (2018) 'Crime and development in the Global South.' In Carrington, K., Hogg, R., Scott, J., and Sozzo, M. (Eds.) The Palgrave Handbook of Criminology and the Global South. Basingstoke: Palgrave. P. 205-221.

Blaustein, J., Pino, N., Fitz-Gibbon, K., and White, R. (2018) 'Criminology and the UN Sustainable Development Goals: The Need for Support and Critique', British Journal of Criminology, 58(4): 767-786.

Blaustein, J., Chodor, T., and Pino, N. (in-press) 'UNODC and the Crime-Development Nexus: From 'drugs and thugs' to 'peaceful and inclusive societies' British Journal of Criminology.

Brangan, L. (2019a) 'Civilizing Imprisonment: The Limits of Scottish Penal Exceptionalism.' British Journal of Criminology, 59(4): 780-799.

Brangan, L. (2019b) 'Pastoral penality in 1970s Ireland: Addressing the pains of imprisonment.' Theoretical Criminology. Online first.

Browne, S. (2011) United Nations Development Programme and System (UNDP). New York: Routledge.

Browne, S. And Weiss, T. (2016 March 1st) 'A UN fit for purpose?' SDGs: delivering change. [blog post] Retrieved from: <https://www.sustainablegoals.org.uk/un-fit- 
purpose/> [Accessed 3 May 2019]

Cardoso, F. (1972) 'Dependency and Development in Latin America' New Left Review, 74(July-August), 83-95.

Carrington, K. and Hogg, R. (2017) 'Deconstructing Criminology's Origin Stories', Asian Journal of Criminology, 12(3): 181-197.

Clark, R. (1994) The United Nations Crime Prevention and Criminal Justice Program: Formulation of Standards and Efforts at their Implementation. Philadelphia: University of Philadelphia Press.

Clifford, W. (1979) Echoes and Hopes: The United Nations Committee on Crime Prevention and Control. Canberra: Australian Institute for Criminology.

Clinard, M. and Abbott, D. (1973) Crime in Developing Countries: A Comparative Perspective. New York: Wiley.

Cowell, A. (1994) 'Laundering of Crime Cash Troubles U.N.' New York Times. November 25: A17. Retrieved from: < https://search-proquestcom.ezproxy.lib.monash.edu.au/docview/429941553?accountid=12528>(Accessed 09 October 2018)

Dos Santo, T. (1970) 'The structure of dependence' American Economic Review, 60(2): 231-236.

Edwards, A. and Gill, P. (2002) 'The politics of 'transnational organized crime': discourse, reflexivity and the narration of 'threat" British Journal of Politics and International Relations, 4(2): 245-270.

Findlay, M. (1999) The Globalisation of Crime: Understanding Transitional Relationships in Context. Cambridge: Cambridge University Press.

Gale, T. (2001) 'Critical policy sociology: historiography, archaeology, and genealogy as methods of policy analysis.' Journal of Education Policy, 16(5): 379-393.

Harvey, D. (2005) A Brief History of Neoliberalism. Oxford: Oxford University Press.

Joutsen, M. (2017) Four transitions in the United Nations Crime Programme. Helsinki: HEUNI. Available at:

<http://www.heuni.fi/material/attachments/heuni/policypaper/g2xEhm7It/FOUR_TRAN- 
SITIONS_IN_THE_UNITED_NATIONS_CRIME_PROGRAMME.pdf $>$ [Accessed 02 August 2018]

Knepper, P. (2009) The Invention of International Crime: A Global Issue in the Making, 1881-1914. Basingstoke: Palgrave.

Knepper, P. (2011) International Crime in the 20th Century: The League of Nations Era, 1919-1939. Basingstoke: Palgrave.

Knepper, P. and Johansen, A. (2016) 'Introduction.' In Knepper, P. and Johansen, A. (Eds.) The Oxford Handbook of the History of Crime and Criminal Justice. Oxford: Oxford University Press. pp. 2-14.

Krohn, M. (1976) 'Inequality, unemployment and crime: A cross-national analysis' Sociological Quarterly, 17(Summer): 303-313.

Lawrence, P. (2016) 'The Historiography of Crime and Criminal Justice.' ' in Knepper, P. and Johansen, A. (Eds.) The Oxford Handbook of the History of Crime and Criminal Justice. Oxford: Oxford University Press. pp. 18-38.

Loader, I. (2006). 'Fall of the 'Platonic Guardians': Liberalism, Criminology and Political Responses to Crime in England and Wales.' British Journal of Criminology, 46(4): 561-586.

Lopez-Rey, M. (1957) 'The First U.N. Congress on the Prevention of Crime and the Treatment of Offenders', Journal of Criminal Law and Criminology, 47(5): 526-538.

Lopez-Rey, M. (1985) A Guide to United Nations Criminal Policy. Aldershot: Gower. McMichael, P. (2017) Development and Social Change. 6th Edition. London: Sage. Merton, R. (1938) 'Social Structure and Anomie', American Sociological Review, 3(5): 672-682.

Messner, S. (1982) 'Societal development, social equality, and homicide: A crossnational test of a Durkheimian model', Social Forces, 61(September): 225-240.

Murphy, C. (1984) Emergence of NIEO Ideology. Boulder: Westview Press.

Murphy, C. (1994) International Organization and Industrial Change: Global Governance since 1850. Oxford: Oxford University Press. 
Murphy, C. (2006) The United Nations Development Programme: A Better Way? Cambridge: Cambridge University Press.

Naik, A. (2013). 'Can the UN Adjust to the Changing Funding Landscape?'. Future United Nations Development System. Briefing 2. March. Retrieved from: < https://futureun.org/media/archive1/briefings/Briefing-2-FINAL.pdf> (Accessed 06 November 2018)

Office of Internal Oversight Services. (2001a). Report on the inspection of programme management and administrative practices in the Office for Drug Control and Crime Prevention. A/56/83. June 1. Retrieved from:

https://oios.un.org/resources/reports/a56_83.htm (Accessed 12 October 2018)

Office of Internal Oversight Services. (2001b). Report of the Office of Internal Oversight Services on the investigation into allegations of misconduct and mismanagement of the "boat project" at the United Nations Office for Drug Control and Crime Prevention.

Panakal, J. and Khalifa, A. (1960) Prevention of Types of Criminality Resulting from Social Changes and Accompanying Development in Less Developed Countries (A/Conf. 17.3.). New York: United Nations.

Redo, S. (2012) Blue Criminology: The Power of United Nations Ideas to Counter Crime Globally. Helsinki: HEUNI. Available at: < http://www.heuni.fi/material/attachments/heuni/reports/6KGSnAmaV/Blue_Criminology _www_linked.pdf> [Accessed 02 August 2018]

Rist, G. (2014) The History of Development: From Western Origins to Global Faith. $3^{\text {rd }}$ Ed. London: Zed Books.

Rock, P. (2002) Constructing Victims' Rights: The Home Office, New Labour and Victims. Oxford: Oxford University Press.

Rostow, W. (1960) The Stages of Economic Growth. Cambridge: Cambridge University Press.

Shaw, C. and McKay, H. (1942) Juvenile Delinquency and Urban Areas. Chicago: University of Chicago Press.

Shelley, L. (1995) 'Transnational Organized Crime: An Imminent Threat to the NationState?' Journal of International Affairs, 48(2): 463-489. 
Tran, M. (2012) 'Mark Malloch-Brown: developing the MDGs was a bit like nuclear fusion.' The Guardian. November 16. Retrieved from:

< https://www.theguardian.com/global-development/2012/nov/16/mark-malloch-brownmdgs-nuclear $>$ [Accessed 16 November 2018]

Transnational Institute. (2005). 'UNDCP overview.' November 17. Retrieved from: https://www.tni.org/es/node/12420 (Accessed 15 October 2018)

'U.N. drug control office in disarray.' (2001) Washington Times. May 14. Retrieved from: https://www.washingtontimes.com/news/2001/may/14/20010514-023022-9288r/ (Accessed 11 October 2018)

United Nations (1954) Yearbook of the United Nations 1954, New York: United Nations. United Nations (1955) First United Nations Congress on the Prevention of Crime and the Treatment of Offenders. [Secretariat's Report]. New York: United Nations.

United Nations (1960) Prevention of Types of Criminality Resulting from Social Changes and Accompanying Development in Less Developed Countries (A/CONF. 17.4.). New York: United Nations.

United Nations (1970) Social Defence Policies in Relation to Development Planning. New York: United Nations.

United Nations (1975a) Changes in Forms and Dimensions of Criminality Transnational and National. New York: United Nations.

United Nations (1975b) Economic and Social Consequence of Crime: New Challenges for Research and Planning. New York: United Nations.

United Nations (1980) New Perspectives in Crime Prevention and Criminal Justice and Development: The Role of International Co-operation. New York: United Nations.

United Nations (1985a) New Dimensions of Criminality and Crime Prevention in the Context of Development: Challenges for the Future. Retrieved from:

< https://www.unodc.org/documents/congress//Previous_Congresses/7th_Congress 198 5/029_ACONF.121.20_Working_Paper_New_Dimensions of Criminality and Crime_Prev ention in the Context of Development.pdf $>$ [Accessed 01 June 2017]

United Nations (1985b). Guiding Principles for Crime Prevention and Criminal Justice in the Context of Development and a New International Economic Order. Retrieved 
from: < https://digitallibrary.un.org/record/114498/files/a-conf-121-22-rev-1-e.pdf>

[Accessed 11 November 2018]

United Nations (1985c) The Milan Plan of Action. Retrieved from:

< https://digitallibrary.un.org/record/114498/files/a-conf-121-22-rev-1-e.pdf> [Accessed

11 November 2018]

United Nations (1990) Crime Prevention and Criminal Justice in the Context of Development: Realities and Perspectives on International Co-Operation. New York: United Nations.

United Nations. (1995). Transnational crime disrupting development and peace. Retrieved from:

< https://www.unodc.org/documents/congress//Previous_Congresses/9th_Congress 199 5/034_Backgrounder Transnational_Crime_Disrupting_Development and Peace.pdf $>$ [Accessed 11 November 2018]

van Dijk, J. (2001). 'Does crime pay? On the relationships between crime, rule of law and economic growth.' Forum on Crime and Society, 1(1): 1-16.

Wacquant, L. (2009) Punishing the Poor: The Neoliberal Government of Social Insecurity. Durham: Duke University Press.

Walters, R. (2001) 'Social Defence and International Reconstruction: Illustrating the Governance of Post-War Criminological Discourse', Theoretical Criminology, 5(2): 203221.

Woodiwiss, M. (2003) 'Transnational organised crime: the global reach of an American concept.' in Edwards, A. \& Gill, P. (Eds) Transnational Organised Crime: Perspectives on Global Security. Abingdon: Routledge.

\section{UNITED NATIONS RESOLUTIONS AND TREATIES}

Criminality and social change, E/RES/1584(L) (21 May 1971). Retrieved from:

$<$ http://www.un.org/ga/search/view_doc.asp?symbol=E/RES/1584(L)> [Accessed 11 November 2018]

Political Declaration. A/RES/S-20/2 (21 October 1998). Retrived from:

<https://www.unodc.org/documents/commissions/CND/Political_Declaration/Political_D eclaration_1998/1998-Political-Declaration_A-RES-S-20-2.pdf> [Accessed 15

November 2018] 
Transforming our world: the 2030 Agenda for Sustainable Development, A/RES/70/1 (25 September 2015) Available at: < http://www.un.org/ga/search/view_doc.asp? symbol=A/RES/70/1\&Lang=E $>$ [Accessed 03 February 2017]

United Nations Convention against Illicit Traffic in Narcotic Drugs. E/CONF.82/15. (20 December 1988). Retrieved from: < https://treaties.un.org/pages/viewdetails.aspx?

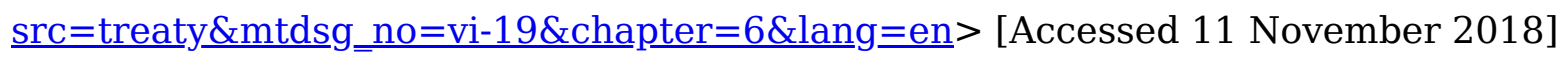

United Nations Convention against Transnational Organized Crime, A/RES/55/25 (8 January 2001) Retrieved from: < https://treaties.un.org/pages/viewdetails.aspx? $\mathrm{src}=$ ind\&mtdsg_no=xviii-12\&chapter $=18 \&$ lang $=\mathrm{en}>$ [Accessed 26 July 2018]

United Nations Convention against Corruption, A/58/422 (31 October 2003) Retrieved from: <https://treaties.un.org/pages/viewdetails.aspx?src=ind\&mtdsg_no=xviii-

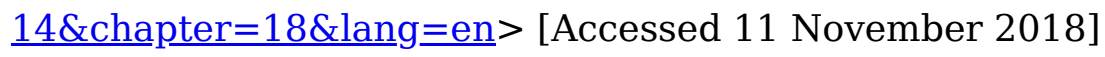

\section{Declaration of Conflicting Interests}

The author(s) declared no potential conflicts of interest with respect to the research, authorship, and/or publication of this article.

\section{Acknowledgements}

Previous versions of this article were presented at: the University of Edinburgh (September 2016); Victoria University Wellington; the University of Liverpool; the American Society of Criminology conference (November 2017); the Australian International Political Economy Network workshop (February 2018); the European Society of Criminology conference (September 2018); the Critical Criminology and Social Justice Conference at the University of New South Wales (September 2018); and the Australia and New Zealand Society of Criminology conference (December 2018). We would like to thank the reviewers along with Richard Ireland and Craig Murphy for their comments on earlier drafts of this paper. We would also like to thank all of the participants who agreed to be interviewed for this project and the gatekeepers who helped us arrange these interviews.

\section{Funding}

The research was supported by internal seed funding provided by the Faculty of Arts at Monash University.

\section{Author Biographies}


Jarrett Blaustein is senior lecturer in Criminology at Monash University. His research focuses on the intersecting nature of global crime and development governance. He is the author of Speaking Truths to Power: Policy Ethnography and Police Reform in Bosnia and Herzegovina (Oxford University Press, 2015) and lead-editor of the forthcoming Emerald Handbook on Crime, Justice and Sustainable Development (2020).

Tom Chodor is lecturer in Politics and International Relations at Monash University. His research focuses on the global governance of the global political economy, and the role of non-state actors in contesting global policy agendas. He is the author of Neoliberal Hegemony and The Pink Tide in Latin America: Breaking Up With TINA? (Palgrave 2015).

Nathan W. Pino is professor of Sociology at Texas State University. He conducts research on policing and police reform in an international context, and the relationships between globalization, crime, and crime control. He is co-author of Globalization, Police Reform and Development: Doing It the Western Way? (Palgrave 2012) and co-editor of Democratic Policing in Transitional and Developing Countries (Ashgate 2006).

\section{Footnotes}

1. Ethical approval was secured from the Monash University Human Research Ethics Committee and the IRB at Texas State University. $\_$

2. This article should be read as a precursor to Blaustein, Chodor and Pino (in-press) which theorises UNODC's efforts to promote recognition of crime as a sustainable development issue following the adoption of the MDGs, and Blaustein, Pino, FitzGibbon and White (2018) which details how criminological issues feature in the 2030 Agenda. Blaustein, Pino and Ellison (2018) further provides an overview of how criminologists have historically theorised the relationship between crime and development. $\triangleq$

3. To this we would add that previous studies of international crime policy formation have consistently adopted a constructivist lens, albeit in conjunction with other theoretical frameworks that provide greater insight into why certain actors, use their power and influence to shape the international agenda and create international regimes (see Knepper, 2011; Andreas and Nadelmann, 2006). 
4. In total, as part of a larger project, we interviewed twenty-seven individuals who possessed direct knowledge of the UN crime programme. We excluded ten of the interviews from the analysis presented in this article and its sister article (Blaustein, Chodor and Pino, in-press) because the participants either lacked direct insight into historical events or we felt that it would be impossible to de-identify the data. Data from the additional interviews will be utilised for future papers that consider how the adoption of the 2030 Agenda has impacted UNODC and the global governance of crime. $\leftrightarrows$

5. Redo (2012: 152) notes that the Social Defence Section was originally established as the Social Defence Unit in 1946.

6. This perspective was grounded in the work of sociological positivists including Shaw and McKay (1942) and Merton (1938) whose foundational ideas remained influential, albeit increasingly scrutinised, in American criminology throughout the 1950s and 1960s. As detailed in Blaustein, Pino and Ellison (2018), these ideas would also later influence pivotal academic studies of crime and development including Clinard and Abbott's (1973) Crime in Developing Countries. $\subseteq$

7. It is worth acknowledging that the decline of social defence funding coincided with the establishment of the United Nations Development Programme (UNDP) as a unified technical assistance fund in 1966 (see Murphy, 2006; Browne, 2011). $\leq$ 8. As detailed in the report, these discussions were triggered by the recommendations by an expert consultative group that met in Geneva in 1968 (see United Nations, 1970: 40). $ヒ$

9. NIEO as a global movement was well dead by 1985, after United States President Ronald Reagan used the 1981 North-South Summit to reject key NIEO demands and instead lecture developing countries about the "magic of the market" as a path to development. A fatal blow was then struck by the 1982 Debt Crisis. Nevertheless, some Member States remained committed to its ideals and they retained some influence within the UN system. $\doteq$

10. Multiple informants emphasised that the diplomatic capital and expert knowledge of individual members of the UN's crime programme were instrumental when it came to mobilizing support for these normative instruments amongst Member States. This suggests that members of the Secretariat directly contributed to the 
political construction of transnational organized crime as a threat to this emergent global liberal order (see Edwards and Gill, 2002; Woodiwiss, 2003).

11. Arlacchi's contribution to the negotiation process is disputed. Arlacchi appears to take credit for these negotiations (see Amuso, 2015) but multiple participants contested this. $\_$

12. The letter was publicly available for download on the website of the Transnational Institute but has since been removed. $\doteq$

13. For Mark Malloch Brown's account of how the MDGs were drafted, see Tran (2012). $\doteq$ 